ISSN 0206-5657. Вісник Львівського університету. Серія біологічна. 2018 Випуск 78. С. 4-5 Visnyk of the Lviv University. Series Biology. 2018. Issue 78. P. 4-5

\title{
HERBARIA IN A CHANGING WORLD
}

\author{
J. Mitka, A. Zemanek, B. Zemanek
}

Botanical Garden of the Jagiellonian University

27, Mikotaja Kopernika St., Kraków 31-501, Poland

e-mail:j.mitka@uj.edu.pl

Similar to other scientific institutions, herbaria are continually tasked with new questions and challenges. They are an important repository of data, dedicated to the storing, identifying, cataloging, and systematic arrangement of botanical specimen for scientific purposes. Traditionally they have been used to validate geographical distributions of species and have served as a basis for the typification of species' names within the scope of Linnaean taxonomy. Herbarium specimens are critical in studies on climate change and biodiversity. Recently, in face of global threats, they are considered the source of qualified information for species monitoring. A fundamental resource in biogeographic studies, herbarium surveys have documented ongoing changes in the geographic ranges of species. An extreme example is the existence of a given species only in the form of herbarium sheets, while in nature it is extinct. In recent times, an especially important role of the herbarium materials is delivering information on the extent and timing of plant invasions posed by human intervention. A new trend is the inclusion of fossil plant materials into paleo-herbaria, which is a subset of traditional Herbarium institutions. Another, still growing function, is the use of plant materials deposited in the herbaria as a source for DNA sampling. This practice poses some threats to plant collections and often is limited by the curators. In general, herbaria constitute a scientific and cultural heritage and are a cornerstone institution for plant and environmental sciences. An alarming trend in the closing of herbaria, by cutting of financial support, is being observed in some countries. Alternatively, in many herbaria, the program of the digitizing these important materials has begun. Now is a critical point in time to work toward a worldwide effort and give these plant and museum collections due recognition.

\section{ГЕРБАРІЇ У СВІТІ, ЯКИЙ ЗМІНЮСТЬСЯ}

\section{J. Mitka, A. Zemanek, B. Zemanek}

\author{
Ботанічний сад Ягеллонського університету \\ вул. Миколая Коперніка 27, Краків 31-501, Польща \\ e-mail:j.mitka@uj.edu.pl
}

Як і в інших наукових установах, у гербаріях постійно постають нові питання та виклики. Гербарії є важливим сховищем даних, присвячених зберіганню, ідентифікації, каталогізації та систематичному розташуванню ботанічного зразка в наукових цілях. Традиційно вони використовувалися для підтвердження географічного поширення видів і слугували основою для типіфікації назв видів у рамках ліннеївської систематики. Зразки гербаріїв $є$ надзвичайно важливими в дослідженнях змін клімату і біорізноманіття. Останнім часом, перед глобальними загрозами, які постають, дані 3 гербарних колекцій вважаються джерелом кваліфікованої інформації для моніторингу видів. Фундаментальний ресурс у біогеографічних дослідженнях гербарії документально підтверджують постійні зміни в географічних ареалах видів. Екстремальним прикладом $€$ наявність даного виду лише у вигляді гербарних аркушів, а у природі він вимер. Останнім часом особливо важлива роль гербарних матеріалів полягає у наданні інформації про ступінь і час інвазії рослин, спричинених втручанням

(C) Mitka J., Zemanek A., Zemanek B., 2018 
J. Mitka, A. Zemanek, B. Zemanek

людини. Нова тенденція полягає також у включенні викопного рослинного матеріалу в палеогербарії, які є підрозділами традиційних гербаріїв. Ще однією функцією, важливість якої дедалі зростає, $є$ використання рослинних матеріалів, які зберігаються в гербарії як джерела для відбору проб ДНК. Ця практика створює певні загрози колекціям рослин і часто обмежується кураторами. Загалом, гербарії є науковою та культурною спадщиною та наріжним каменем інституції наук про рослини і навколишнє середовище. У деяких країнах спостерігається тривожна тенденція до закриття гербаріїв, скорочення їхньої фінансової підтримки. Як альтернатива у багатьох гербаріях розпочалася реалізація програм оцифрування цих важливих матеріалів. Тепер настав критичний час у праці над тим, аби цінність і важливість гербарних та музейних колекцій рослин були належним чином визнані у світі. 